\title{
Development of Cost Effective Solar Tent Fish Dryer as a Climate Smart Agricultural Technology for the West African Sub-Region
}

\author{
J.O. Olokor \\ National Institute for Freshwater Fisheries Research (NIFFR), \\ P.M.B 6006, New Bussa, Niger State \\ Nigeria.
}

\begin{abstract}
A Climate Smart Agricultural Technology using exclusively energy from the Sun was developed for rural fish processors in West Africa. The dryer was made of metal has been fabricated. This dryer can be dismantled and thus very portable unlike the old one made of wood and very bulky. Studies on the physical, chemical, biological and nutritional status of the solar dried fish compared to those dried in the open sun, show significant differences at 5\% significance level using ANOVA, $(p<0.05), P=0.03$. The Solar dryer is still being modified to improve its efficiency. It has enjoyed huge popularity around Kainji and Jebba Lakes in the past. There is a need to extend it to other West Africa countries with semi-arid conditions.
\end{abstract}

Keywords: Agricultural Technology, Global warming, solar tent dryer.

\section{INTRODUCTION}

As climate change and global warming continues to take their tolls in Africa and particularly West Africa, climate smart technologies appear to be the best alternatives available for rural farmers in the struggle to adapt to climate change. Armed with poor farm tools and little scientific technological know-how, farmers in these regions are more and more relying on indigenous and cultural practices to mitigate the severe impacts of climate change threatening their livelihoods.

In West Africa, fish processors are faced with severe fuel wood shortages and are gradually shifting to sun drying as a method of preservation. Salting, smoking and other forms of drying have been used traditionally for preserving fish in West Africa. Sun drying in particular is common around Lakes Chad, Kainji, Jebba some other parts of Nigeria. Traditional methods of sun drying involve spreading fresh fish on the ground, mats or grass to dry. Since fish is an extremely perishable food item, when dried using this local method, it often go bad during the process because the prevailing ambient conditions of relative humidity and temperature favourable for efficient drying is not attained (Olokor, 2006).

Spoilage of locally sun-dried fish also results from insect pest infestation such as blowflies which lay their eggs on exposed fish during the drying process. Fish spoilage in Nigeria resulting from insect infestation alone is put at 20\% (Eyo, 2001). Other short comings of traditionally sun dried fish are: contamination by dust, sand and stones due to poor processing methods. These short comings, coupled with foul smell arising from partial spoilage, poor taste and hygiene have made the product to command lower prices compared to their imported stockfish counterpart.

\section{MATERIALS AND METHODS}

The WAAPP solar tent dryer (WSTD) is an improvement on the Kainji Solar Tent dryer (KSTD) developed at NIFFR in 1996. The present design is thus a product of nearly two decades of research. The earlier design by Doe and others (1977) consists of a transparent polyethylene sheet worn over a bamboo-tent` shaped structure. The polyethylene is transparent to incoming solar radiation but opaque to outgoing terrestrial radiation. As such, there is a buildup of heat within the dryer causing the air within the dryer to be heated. Openings at the base of both sides of the dryer allow cooler air to be drawn in, and vents in the apex at both ends allow the warm air to escape.

\subsection{The Solar tent dryer}


The WAAPP design (WSTD) is made of dis-mountable $2.5 \mathrm{~cm}$ hollow pipes. It is rectangular in shape with the vertical height being longest. The transparent polyethylene cover is fitted with screened vents and a zip for access. There are black rocks at the base and up to 5 removable drying racks are fitted to the structure to accommodate more fish.

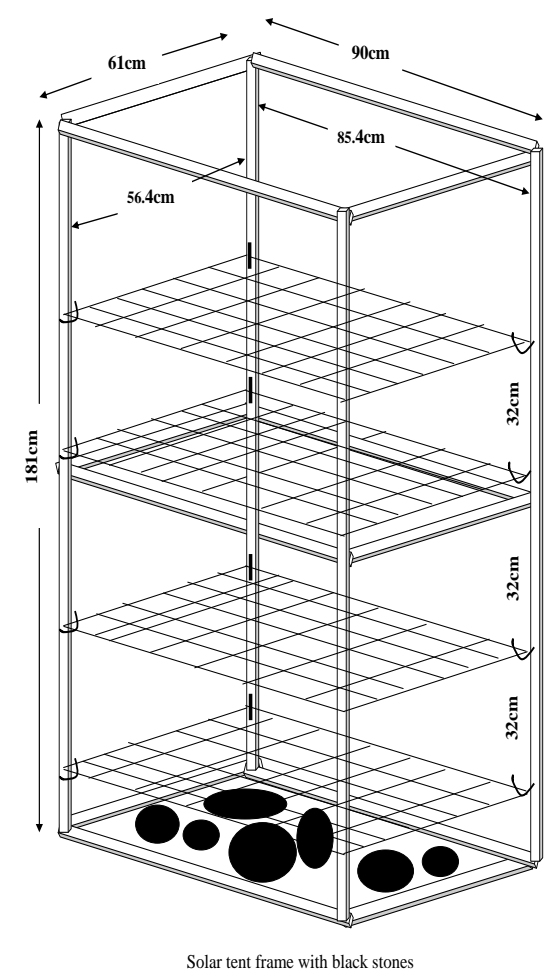

Fig 1: Sketch of solar Dryer

\section{RESULTS AND DISCUSSION \\ 3.1 Product Quality}

Some physical, biological and chemical analyses were done on fish products dried in solar dryers and those with the traditional, open sun method, to be sure that the products are healthy, nutritious and palatable for consumption.

Table 1, shows an assessment by a panel of ten members. It shows that fish in the solar dryer scored a mean of 8.2 in terms of appearance, compared to 5.2 for open sun dried fishes. Fishes in the solar dryer scored 7.8 in terms of texture compared to 6.6 for sun-dried fishes. In terms of odour, fishes in solar dryer scored 8.2 while those in open sun scored 4.6. For taste, the fishes in solar dryer scored 8.4 while those in the open sun scored zero because no member was willing to taste it due to its foul smell. The results show preference for solar dried fish. At 5\% significance level, Analyses of Variance shows that there was a significant difference $(\mathrm{p}<0.05), \mathrm{P}=0.03$ between both treatments.

Table 1. Organoleptic assessment of fish inside and outside solar dryer

\begin{tabular}{|l|c|c|}
\hline $\begin{array}{l}\text { Organoleptic } \\
\text { Quality }\end{array}$ & $\begin{array}{l}\text { Solar dryer } \\
\text { (Mean Score) }\end{array}$ & $\begin{array}{l}\text { Sun drying } \\
\text { (Mean Score) }\end{array}$ \\
\hline Appearance & 8.2 & 5.2 \\
Texture & 7.8 & 6.6 \\
Odour & 8.2 & 4.6 \\
Taste & 8.4 & - \\
\hline
\end{tabular}

\subsection{Product Physical Quality}

Visual observation of the final dried products reveals that the solar dried fishes were of better quality compared to the traditional open sun dried fish. The texture was hard and well dried and the products had a pleasant odour. All the 3 treatments within the solar tent dryer were of a light, whitish, yellow colour, while those outside were dark orange, showing signs of rancidity. Sun dried products were of poor quality, because of the low initial temperature and high relative humidity. But the solar dryer provided suitable conditions for fast drying, which discouraged bacterial attack. However, at the end of the drying session, sun 
dried fishes improved in quality though, not comparable to the solar dried fishes but were observed to have sand, dirt, dust and ants on them. But those inside the solar dryer were cleaner.

\subsection{Assessment of microbial load}

Table 2, shows that fish dried in the open sun which is the traditional practice had the highest concentration of Total Viable Count (TVC) and thus less suitable for consumption. This is because it underwent spoilage due to poor drying resulting from ambient conditions. This indicates the need for solar dryers which improve ambient conditions as could be seen from the table, where samples from the solar tent dryer had the least average microbes of $43.3 \mathrm{cfu} / \mathrm{g}$ compared to $132 \mathrm{cfu} / \mathrm{g}$ of open sun dried fish. Fresh fish recorded $64.3 \mathrm{cfu} / \mathrm{g}$ numbers of microbes. Although both products fall within the acceptable $\operatorname{limits} \mathrm{of} 5.7 \mathrm{log}_{10} \mathrm{cfg} / \mathrm{m}$, according to the International Commission of Microbiological specification for food (1986), the lower the microbial load, the better. As such the solar dried fish is healthier than those dried in the open sun

Table 2: Microbial assessment (cfu/gm) of sun dried fish and solar dried fish.

\begin{tabular}{|c|c|c|c|c|}
\hline & TVC & TVC & TVC & Average \\
\hline Sample & A & B & C & \\
\hline Open Sun dried fish & 162 & 163 & 71 & $132 \mathrm{cfu} / \mathrm{g}$ \\
\hline Fish in solar dryer & 79 & 39 & 12 & $43.3 \mathrm{cfu} / \mathrm{g}$ \\
\hline Fresh fish & 137 & 49 & 8 & $64.3 \mathrm{cfu} / \mathrm{g}$ \\
\hline
\end{tabular}

\subsection{Percentage proximate analyses}

Results of the proximate analyses composition shows that moisture content of fish in the solar dryer was reduced to $10.6 \%$ compared to $22.26 \%$ for fish dried under direct sunlight. The low moisture content of solar dried fish makes it more resistant to bacterial attack compared to open sun-dried fish as shown previously. Table 3 shows that fresh fish is made up of $78.96 \%$ water and the dryer was able to bring this down to $10.6 \%$.

The level of protein in the three samples shows that sun dried fish (both sun and solar dryer) had more percentage crude protein than fresh fish. Fresh fish had $21.74 \%$, fish in the dryer had $82.14 \%$ and fish outside had $62.3 \%$. Thus solar dried fish is more proteinous than fresh fish or those dried in the open sun. The table further shows that open sun-dried fish had more fat (ether extract) of $16.25 \%$ compared to $8.46 \%$ of fish in the dryer and $0.35 \%$ of fresh fish. The high percentage ether extract of sun dried fish results from its poor drying process leading to rancidity. Analysis of variance shows that there was a significant difference in both qualities of fish $(\mathrm{P}=0.003)$ at $5 \%$ significant level. These results from proximate analyses confirm that fish dried in the solar dryer is healthier and more nutritious than the one sun-dried.

Table 3: Percentage analyses of fresh, sun dried and solar dryer fish

\begin{tabular}{|c|c|c|c|c|c|}
\hline $\begin{array}{c}\text { Sample } \\
\text { Identification }\end{array}$ & $\begin{array}{c}\text { \% moisture } \\
\text { content }\end{array}$ & $\begin{array}{c}\text { \%Either } \\
\text { extract }\end{array}$ & $\begin{array}{c}\text { \% crude } \\
\text { fibre }\end{array}$ & $\begin{array}{c}\text { \%crude } \\
\text { protein }\end{array}$ & $\begin{array}{c}\text { Nitrogen free } \\
\text { extract }\end{array}$ \\
\hline Fresh fish & 78.96 & 0.35 & 1.40 & 21.74 & Nil \\
\hline $\begin{array}{c}\text { Fish inside } \\
\text { dryer }\end{array}$ & 10.60 & 8.46 & 0.40 & 82.14 & Nil \\
\hline $\begin{array}{c}\text { Fish dried in } \\
\text { open sun }\end{array}$ & 22.26 & 16.25 & 0.72 & 62.3 & Nil \\
\hline
\end{tabular}

\section{CONCLUSION}

The solar dried fish developed at NIFFR has a similar taste, colour and appearance as the imported stockfish from Norway. The dried fish could therefore contribute to the stock fish trade. The NBF (2010) reported that Nigeria alone imports about 18,000 metric tonnes running into Billions of Naira annually.

The production of dried fish in West Africa is normally in the open sun without solar dryers or in the fermented form. Despite the short comings associated with these traditional forms of processing, it is still a big business employing hundreds of thousands of artisanal processors mainly women. This business has flourished over the years, providing the livelihoods of many locals because the methods of processing are simple and require little or no technology, the high demand for the products as local delicacies and thirdly because sun drying helps to reduce post-harvest losses. 
The use of the newly developed WAAPP solar dryer will be a big boost to this local industry by improving the quality of final products. The dryer ensures faster drying thus increased freshness; prevent dirt, sand and dust etc. However, there is need to commit enough funds to this project to further improve the efficiency of the dryer and to promote the already existing one to other West African countries.

\section{REFERENCE}

1. Doe, P.E. Ahmed, M, Muslemuddin, and Sachithanathan, K (1977) A polyethylene tent Dryer for improved Sun drying of fish, Food technology in Australia, 29, 437 - 441

2. Eyo, A.A. (2001) Fish Processing Technology in the Tropics. UNILORIN Press. Pp 130-152

3. NBF News (2010) http://www.thenigerianvoice.com/nvnews/38316/1/18-000-tons-of-stock-fish-imported-into-nigeriaann.html

4. Olokor (2006) Adaptation of Solar Tent Dryer for Fish Preservation: Implications for Forest Resources Conservation around Kainji Lake, Nigeria. Presented to Department of Geography, Federal University of Technology, Minna, April 2006. Unpublished Ph.D. Thesis $165 \mathrm{Pp}$

5. Trim, D. S. and C. A. Curran (1983). A comparative study of solar and sun drying of fish in Ecuador Tropical Product Institute 56 / 62 Gray`s inn Road. London. Pp 11 - 17. 